\title{
Environmental Costs Account: a base for measuring sustainability in transport plans
}

\author{
Andres Monzon, Alvaro Fernandez, Pablo Jorda \\ TRANSyT-Transport Research Centre. Universidad Politecnica de Madrid
}

\begin{abstract}
Each city need to develop sustainable transport plans according to its future developments. This means identifying the best policy package of transport measures that could produce more sustainable future scenarios: lowest environmental impact, but also better social standards and at minimum cost. To that end, it is necessary to measure the environmental and social costs of each alternative transport mode. This paper proposes a methodology to calculate those costs in different city contexts: city centre and metropolitan suburbs. It provides a measure of the following environmental costs: pollution, noise, green house gasses and land taken. Then the social costs as congestion and accident costs. These two cost categories are calculated for each mean of transport: metro, bus, private car and taxi. The methodology has been applied to Madrid Region through modeling its mobility demand in 2004. The outputs are costs per passenger-km in each mode and Area: city centre and metropolitan ring. Therefore it is possible to assign monetary costs to environmental and social costs of each transport option; for example, car environmental costs are four times higher than buses on average, but it differs a lot from city centre to outskirt areas. Finally, some guidelines can be extracted to develop a more sustainable transport policy for Madrid Region.
\end{abstract}

\section{Assessment of environmental costs in urban areas}

Achieving sustainable mobility in urban areas means to reconcile environmental protection with social well-being and economic development. These targets include reducing the negative impacts from transport, including pollution, noise and congestion, while ensuring affordable, accessible 
and safe mobility, without affecting the living conditions of future generations $[1,21]$.

To measure how sustainable mobility is achieved we need to settle a number of indicators [5]. However, the assessment methods of transport policies more often use time and cost indicators rather than environmental ones [22]

The approach adopted to analyze transport sustainability is to develop the socio-environmental account of transport means for each specific city or region [3]. This integrated approach considers all transport externalities in a comparative way and is a good tool for planning taken into account social fairness $[15,18,19]$. We have used these concepts making the travelers transport account of Madrid. In this account, we have worked with social costs like a way for analyzing the sustainable transport.

This kind of assessment has been improved over time (decades) by including more factors [6, 7]. Thus, in Europe we can find several transport studies dealing with counts of general social cost or externalities at a national, regional or urban level $[23,25]$.

In this paper, we show the importance of urban and metropolitan environmental cost among various diverse transports modes. We will analyze the results of the Madrid case study and we will point to guidelines for a more sustainable development in cities.

\section{Social transport account: how to measure.}

Environmental costs and externalities allocation are necessary to calculate the optimum social costs and sound basis to reduce global car mobility in cities [14].

Sustainable mobility is linked to the model for urban development in each city $[4,9,10,13]$. Suburban sprawl causes trips that are cheaper for user but generate more global mobility and less social welfare. The internalization of externalities can correct this process [26].

To deal with this kind of effects we need to know the social cost of all kind of trips, for each city zone and transport mode [20]. In the transport account presented here, we have used disaggregated data to provide detailed results for different geographical zones which influence the costs of trips: urban and metropolitan.

Transport social cost is the cost paid for an individual trip by the whole society. These costs have two components, one is internal and the other external. The cost structure is different for every transport mode, so we can use that cost account for comparing the performance of trips made with different modes. In this study we have taken into account the following 
modes: urban bus, suburban bus, metro, suburban train, car, taxi, and walking (in Madrid bikes are not representative nowadays).

The kind of costs we took into account include: infrastructure, operating cost, travel time, accidents, noise, air pollution, global warming and land taken. We have given special attention to externalities within social cost, although we have not taken into account some externalities such as downstream processes because they are still not significant [25].

Table 1. Costs appraised in the study

\begin{tabular}{ll}
\hline Cost & Cost elements \\
\hline Infrastructures & capital costs of investments and replacement of assets, running costs for maintenance \\
Operating costs & vehicle related costs, cost of personnel and administrative costs \\
Travel time & time spent in traveling: access, waiting, trip and dispersion \\
Accidents & risk value, human capital losses, medical care, administrative costs, damage to property \\
Noise & human health impact, damage to property \\
Air pollution & human health impact, environmental damage, damage to building structures \\
Global warming & climate change, impact of energy use, impact of environment \\
Land taken & loss of habitat, landscape charge \\
\hline
\end{tabular}

We have made use of different cost methodologies, developed for previous studies, for each cost category [8, 20,23, 25]. Then we had to adapt them to the specific case and values of the Madrid Metropolitan Area. Several previous studies have already been carried out in Spain on transport externalities costs in urban areas, both in Barcelona [24] and Madrid [16]. This study is based in the latter, but its methodology has been improved and applied to the 2004 Madrid Region mobility survey [11].

\section{Madrid metropolitan area Case Study: structure and mobility patterns}

Madrid is the capital city of Spain. It is a city of 3.1 million inhabitants, surrounded by its Metropolitan Ring with a population of 2.3 million. Demographic density and job distribution varies considerably (see Table 2 and Fig. 1), where the core part (CBD) plays a big role. These differences have substantial effects on mobility patterns. 
Table 2. Social Indicators. Madrid metropolitan area, 2004

\begin{tabular}{|c|c|c|c|c|c|c|}
\hline & & Inhabitants & $\begin{array}{r}\text { Surface area } \\
\left(\mathrm{km}^{2}\right)\end{array}$ & $\begin{array}{l}\text { Density } \\
\text { (inh/ha) }\end{array}$ & Jobs & Jobs/1000 inh \\
\hline \multirow{2}{*}{$\begin{array}{l}\text { Madrid } \\
\text { municipality }\end{array}$} & CBD & 1018732 & 42 & 243 & 959877 & 942 \\
\hline & Periphery & 2116513 & 564 & 38 & 815648 & 385 \\
\hline \multicolumn{2}{|c|}{ Metropolitan Ring } & 2328494 & 2086 & 11 & 893982 & 384 \\
\hline \multicolumn{2}{|l|}{ Total } & 5463739 & 2692 & 20 & 2669507 & 489 \\
\hline
\end{tabular}

For the purpose of this study we have considered two different types of trips:

- Urban trips: origin and destination in Madrid city (either CBD or periphery)

- Metropolitan trips: origin and/or destination in the Metropolitan Ring
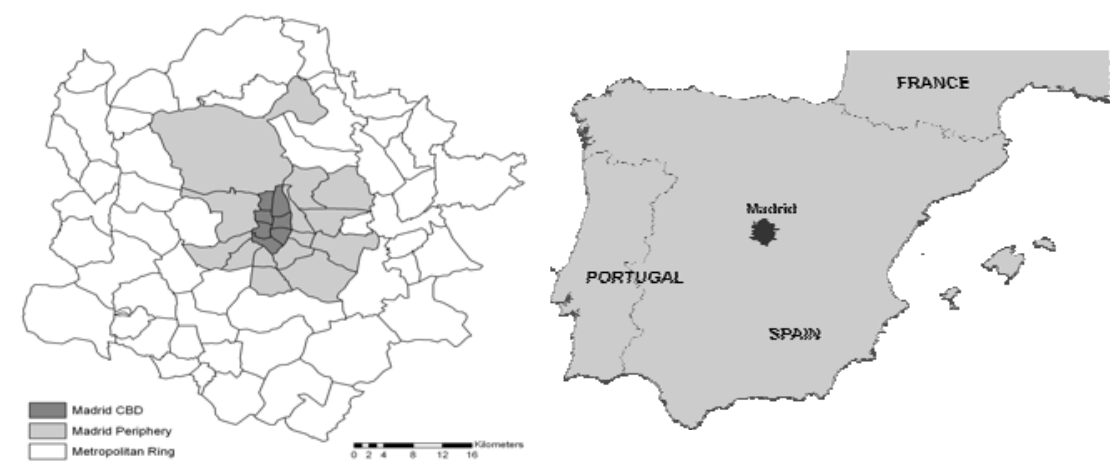

Fig.1. Madrid Metropolitan Area zones

The use of different transport modes is rather different between Madrid City and its Metropolitan ring (Table 3). Public transport (PT) is the most important transport mode in the denser central city districts whereas the car is dominant in the suburbs. The number of walking trips is on the rise in the city centre and is falling in favor of car use in the metropolitan ring. Very few trips are made by bicycle, just $0.1 \%$ in the urban area. Madrid City has a good mobility performance rating but car trips are increasing at a faster rate than trips by public transport or on foot. Car trips predominate in the metropolitan ring and are growing very rapidly, which is a clear threat for the future [2]. According to the 2004 mobility survey [11] PT accounts for 38\% of trips in Madrid City and only 24\% in the Metropolitan 
Ring; car patronage was $29 \%$, and $45 \%$ respectively; while $32 \%$ are walking trips in Madrid City and 30\% in the Metropolitan Ring.

Table 3. Modal split in Madrid Metropolitan Area, 2004

\begin{tabular}{lrrrr}
\hline & Urban trips & \multicolumn{3}{c}{$\begin{array}{c}\text { Metropolitan } \\
\text { trips }\end{array}$} \\
Mode & & \multicolumn{3}{c}{$\%$} \\
Urban Bus & 1186588 & 15.5 & 7535 & 0.1 \\
Metro & 1525463 & 19.9 & 224268 & 3.7 \\
Suburban Bus & 33835 & 0.4 & 735463 & 12.1 \\
Suburban Train & 173052 & 2.3 & 513909 & 8.5 \\
Public Transport & 2918938 & 38.2 & 1481175 & 24.4 \\
Car & 1716583 & 22.4 & 2700828 & 44.5 \\
Taxi & 508319 & 6.6 & 24804 & 0.4 \\
Motorbike & 52818 & 0.7 & 30469 & 0.5 \\
Walking & 2449839 & 32.0 & 1835742 & 30.2 \\
Total & $\mathbf{7 6 4 6 4 9 7}$ & $\mathbf{1 0 0 . 0}$ & $\mathbf{6 0 7 3 0 1 8}$ & $\mathbf{1 0 0 . 0}$ \\
trips/inhabitants & 2.44 & & 2.61 & \\
trips/inhabitants (1996) & 2.13 & & 2.04 & \\
\hline
\end{tabular}

Comparing data from the two last mobility surveys 1996-2004, the first observation to make is that the mobility rate has been on the rise a lot. In Madrid City, it has increased from 2.13 to 2.44 (15\%) trips per person over the 1996-2004 period [11, 12]. In the Metropolitan Ring the rate has grown even more: from 2.04 to 2.61 (28\%) trips per person. This is mainly due to the increase of car trips in the Metropolitan Ring by $75 \%$.

This change in mobility patterns has a big environmental impact and it is causing a vicious circle which will produce more car dependency and again more environmental costs.

\section{Transport costs in Madrid}

The transport costs evaluated in this study are €21.7 billions for the whole Madrid Metropolitan Area (Table 4). Trip time is two thirds of this total, and economic costs explain another $28 \%$. This explains why in the assessment process of transport projects is given very low importance to externalities, including accidents and environmental costs. Externalities account only €883 million, which means about a 4\%. 
Table 4. Transport costs distribution (Mill. $€_{2004}$ )

\begin{tabular}{lrrrrrrrrr}
\hline \multicolumn{1}{c}{ Economic costs } & \multicolumn{7}{c}{ Externalities } \\
& $\begin{array}{c}\text { Infrastruc- } \\
\text { tures }\end{array}$ & $\begin{array}{c}\text { Operating } \\
\text { costs }\end{array}$ & $\begin{array}{c}\text { Travel } \\
\text { time }\end{array}$ & $\begin{array}{c}\text { Acci- } \\
\text { dents }\end{array}$ & $\begin{array}{c}\text { Noise } \\
\text { Air } \\
\text { pollu- } \\
\text { tion }\end{array}$ & $\begin{array}{c}\text { Global } \\
\text { warming }\end{array}$ & $\begin{array}{c}\text { Land } \\
\text { taken }\end{array}$ & Total \\
$\begin{array}{l}\text { Urban } \\
\text { trips }\end{array}$ & 229 & 3431 & 7325 & 124 & 56 & 137 & 33 & 1 & 11335 \\
$\begin{array}{l}\text { Metropoli- } \\
\text { tan trips }\end{array}$ & 154 & 2358 & 7322 & 239 & 53 & 118 & 82 & 40 & 10366 \\
Total & $\mathbf{3 8 2}$ & $\mathbf{5 7 8 9}$ & $\mathbf{1 4 6 4 7}$ & $\mathbf{3 6 3}$ & $\mathbf{1 0 9}$ & $\mathbf{2 5 5}$ & $\mathbf{1 1 5}$ & $\mathbf{4 1}$ & $\mathbf{2 1 7 0 1}$ \\
\hline
\end{tabular}

Analyzing trip costs according to transport mode we can see big differences for all kinds of costs and for the Area where trips are made [3]. Table 5 shows the results in costs per passenger-kilometer according to urban and metropolitan modes. In urban trips, collective public transport is the most competitive. Car cost is practically twice metro cost, and the metro is the most efficient transport mode in urban trips. However, in metropolitan trips, costs for different transport modes are more similar. In other words, car is more competitive from the social point of view. Suburban train and bus trips are less costly from a social point of view, but differences are not big enough to influence a move in trips from car use.

Table 5. Costs by transport mode, $2004\left(€_{2004} / 100\right.$ pass-km)

\begin{tabular}{|c|c|c|c|c|c|c|c|}
\hline & \multicolumn{4}{|c|}{ Urban trips } & \multicolumn{3}{|c|}{ Suburban trips } \\
\hline & Urban bus & Metro & Car & Taxi & $\begin{array}{c}\text { Suburban } \\
\text { bus }\end{array}$ & $\begin{array}{l}\text { Suburban } \\
\text { train }\end{array}$ & Car \\
\hline Infrastructures & 0.35 & 2.71 & 1.90 & 2.10 & 0.07 & 1.69 & 0.37 \\
\hline Operating costs & 16.31 & 9.14 & 52.68 & 37.55 & 5.78 & 5.87 & 12.15 \\
\hline Travel time & 56.71 & 44.26 & 42.79 & 48.60 & 23.29 & 23.68 & 23.18 \\
\hline Economic costs & 73.37 & 56.11 & 97.37 & 88.25 & 29.14 & 31.24 & 35.70 \\
\hline Accidents & 0.67 & 0.08 & 1.07 & 1.24 & 0.14 & - & 1.06 \\
\hline Noise & 0.19 & - & 0.82 & 0.90 & 0.08 & - & 0.31 \\
\hline Air pollution & 0.76 & 0.03 & 1.94 & 2.12 & 0.30 & 0.03 & 0.67 \\
\hline Global warming & 0.09 & 0.06 & 0.52 & 0.56 & 0.05 & 0.06 & 0.52 \\
\hline Land taken & - & - & 0.01 & 0.01 & 0.04 & 0.05 & 0.24 \\
\hline Externalities & 1.71 & 0.17 & 4.36 & 4.83 & 0.61 & 0.15 & 2.80 \\
\hline Total & 75.08 & 56.28 & 101.73 & 93.08 & 29.74 & 31.39 & 38.50 \\
\hline
\end{tabular}

We have to bear in mind also the average trips distances in each Area. Urban trips made by public transport have an average distance of $7.1 \mathrm{~km}$ 
while car trips are $7.9 \mathrm{~km}$. This means that unitary costs in public transport are lower than in car, and also trips distances are more competitive. In the Metropolitan Area we find the opposite situation: average public transport trip is $21.4 \mathrm{~km}$ long, while in car it is $16.3 \mathrm{~km}$.

The conclusion is that in urban areas it is possible to attract more trips towards public transport modes, but in the suburbs this is quite difficult. Public transport is a good competitor against cars in denser central areas both from the travelers and from the social point of view. On the contrary, it has clear disadvantages when it is operating in urban sprawl zones. In these Areas it is less competitive: longer trips distances and higher social and economic costs [9].

\section{Externalities of transport modes in Madrid}

If we focus our analysis only on the accidents and the environmental part of the total costs of transport, we see a very different picture both for urban and for metropolitan trips [17].

In both Areas, rail modes (metro and suburban rail) present the lowest rate of externalities. Then buses came second, and the highest externalities correspond to cars.

In urban trips metro account only $€ 1.7$ per 1000 passenger-km (Table 6). Urban buses externalities are about $€ 17.2$ that is 10 times higher. Car and taxi reach more than €43.7, almost 25 times more. Among externalities, air pollution is the most important for urban trips. It accounts for about half of the car externalities and a high share of the buses.

Table 6. Urban trips. Externalities costs $\left(€_{2004} / 1000\right.$ pass-km)

\begin{tabular}{lrrrr}
\hline & Urban bus & Metro & Car & Taxi \\
Accidents & 6.75 & 0.76 & 10.75 & 12.35 \\
Noise & 1.88 & - & 8.22 & 8.97 \\
Air pollution & 7.64 & 0.33 & 19.41 & 21.19 \\
Global warming & 0.87 & 0.62 & 5.16 & 5.63 \\
Land taken & 0.01 & - & 0.11 & 0.11 \\
Total & $\mathbf{1 7 . 1 5}$ & $\mathbf{1 . 7 1}$ & $\mathbf{4 3 . 6 4}$ & $\mathbf{4 8 . 2 6}$ \\
\hline
\end{tabular}

In the case of metropolitan trips (Table 7), suburban rail accounts only $€ 1.5$ per 1000 passenger-km, the same cost as metro in urban trips. The other modes have lower unit costs than in the urban part, due to less con- 
gestion in the suburbs. However, trip distances are more than doubled: $18.1 \mathrm{~km}$ in the suburbs against $7.4 \mathrm{~km}$ for Madrid city trips. Comparing costs among suburban trips in the different modes, rail based trips have again the best performance in externalities. Bus externalities are 4 times higher and those related to car trip externalities are 19 times. The share of externalities corresponding to air pollution is still the most important, but lower than in urban Areas. On the contrary, accidents are more relevant, with a cost of $€ 10$ per 1000 pass-km made by car.

Table 7. Metropolitan trips. Externalities costs $\left(€_{2004} / 1000\right.$ pass-km)

\begin{tabular}{lrrr}
\hline & Suburban bus & Suburban train & Car \\
Accidents & 1.39 & - & 10.64 \\
Noise & 0.79 & 0.02 & 3.07 \\
Air pollution & 2.96 & 0.32 & 6.69 \\
Global warming & 0.54 & 0.58 & 5.16 \\
Land taken & 0.37 & 0.54 & 2.44 \\
Total & $\mathbf{6 . 0 5}$ & $\mathbf{1 . 4 6}$ & $\mathbf{2 8 . 0 0}$ \\
\hline
\end{tabular}

\section{Recommendations for more sustainable transport policy in Madrid}

The results of this study have two main findings. The methodology developed to assess social and environmental costs of transport modes has proved to be useful. Firstly, it enables us to compare mobility impacts on different type of city developments: low and high density Areas, good and poor Public Transport supply, etc [19]. Secondly, its application to Madrid Metropolitan Area point out a number of policy guidelines to achieve more sustainable mobility patterns in each part of the city.

The urban development of Madrid City has a clear benefit both from the economic and environmental point of views. Denser developments are more PT oriented than those in the Metropolitan sprawl. Costs for the user, for society, and for the environment clearly fosters a higher concentration of activities in the city. The length of trips in dense city centers is about 2.5 times than those in the Metropolitan ring. City centre trips could be made on foot, cycling or by PT, while trips in the Metropolitan ring are more convenient for car.

Therefore we can conclude two urban policy guidelines. The revitalization of city centers brings economic and environmental benefits. They improve the life of the citizens, because they are less dependent on car trips. 
On the contrary low density developments bring more costs in the long term, resulting in less sustainable forms of city development [10].

Finally, big cities profit from the good supply of rail modes: metro in the central part and suburban rail in the suburbs. Although they require big investments, there are clear benefits in the long run. They produce much less operating and environmental costs because their capacity is higher and their technology is less harmful.

In summary, decision-makers in cities can use social and environmental transport cost accounts to help them with decisions in providing urban transportation. The socio-economic and environmental points of view provide complementary views on their duties. Technicians who help them also benefit from transport accounts. They provide a clear valuation of all transport costs in a comparative way [3, 14].

\section{References}

1. Åkerman J, Höjer M (2006) How much transport can the climate stand? Sweden on a sustainable path in 2050. Energy Policy, 34:1944-1957

2. Bamberg S (2003) Does habitual car use not lead to more resistance to change of travel mode? Transportation 301

3. Banister D (2008) The sustainable mobility paradigm. Transport Policy, 15:73-80

4. Bertolini L, le Clercq F, Kapoen L (2005) Sustainable accessibility: a conceptual framework to integrate transport and land use plan-making. Two testapplications in the Netherlands and a reflection on the way forward. Transport Policy, 12:207-220

5. Black JA, Paez A, Suthanaya PA (2002) Sustainable Urban Transportation: Performance Indicators and Some Analytical Approaches. Journal of urban planning and development 128:184-209

6. Boiteux M (2001) Transports: choix des investissements et côut des nuisances:325. Commissariat General du Plan, Paris

7. Button K, Quinet E, Kageson P, Bleijenberg A, Rothengatter W, Banister D, Vreckem D and Bonnafous A. (1994) Internalizing the social cost of transport: 191. European Conference of Ministers of Transport; Organization for Economic Co-operation Develepment, Paris

8. CERTU (2005) Etablir un compte déplacements à échelle locale: 128. CERTU, Paris

9. Chen H, Jia B, Lau SSY (2008) Sustainable urban form for Chinese compact cities: challenges of a rapid urbanized economy. Habitat International, 32:2840

10. Cram J (2006) Urban form and sustainable transport. Journal of Transport Geography 14:226 
11. CRTM (2006) Encuesta Domiciliaria de Movilidad en día laborable de 2004 en la Comunidad de Madrid. Resumen de resultados. Consorcio Regional de Transportes de Madrid, Madrid

12. CRTM (1998) Encuesta Domiciliaria de Movilidad en día laborable de 1996 en la Comunidad de Madrid. Análisis y síntesis de la movilidad. Consorcio Regional de Transportes de Madrid, Madrid

13. Curtis C (2008) Planning for sustainable accessibility: The implementation challenge. Transport Policy, 15:104-112

14. De Borger B, Wouters S (1998) Transport externalities and optimal pricing and supply decisions in urban transportation: a simulation analysis for Belgium. Regional Science and Urban Economics, 28:163-197

15. Gudmundsson H, Höjer M (1996) Sustainable development principles and their implications for transport. Ecological Economics, 19:269-282

16. Guerrero MJ, Monzón A (2003) Cuenta económica y socio-ambiental del transporte terrestre de viajeros en la Comunidad de Madrid en 1996: 184. Consorcio Regional del Transporte de Madrid, Madrid

17. Himanen V, Lee-Gosselin M, Perrels A (2005) Sustainability and the interactions between external effects of transport. Journal of Transport Geography, $13: 23-28$

18. Litman T, Burwell D (2006) Issues in sustainable transportation. Global environmental issues 6:331-347

19. Litman T (1999) Transportation Cost Analysis for Sustainaibility: 1-17

20. Maibach M, Schereyer C, Sutter D, Essen HP, Boon B H, Smokers R, Schroten A, Doll C, Pawlowska B and, Bak, M. (2007) Handbook on estimation of external cost in the transport sector: 332. CE Delft, Delft

21. May AD (2003) Developing Sustainable Urban Land Use and Transport Strategies: a Decision Makers' guidebook, PROSPECTS. Deliverable $n^{\circ} 5$. European Commission, 5th Framework

22. Monzón A (2006) Externalidades del transporte y ferrocarriles urbanos. Ingeniería y territorio 76:32-39

23. Nash C (2003) UNIfication of accounts and marginal costs for Transport Efficiency. Final Report.: 60. Institute for Transport Studies, University of Leeds. 5th Framework Programme. European Commission, Leeds

24. Robusté R, Margín J, Alsius F, Lorente A, Monzon A, Hormigo E and Subira E. (2000) Els Comptes del Transport de Viatgers a la Regió Metropolitana de Barcelona. Any 1998: 219. Autoritat del Transport Metropolitá, Barcelona

25. Schereyer C, Schneider C, Maibach M, Rothengatter W, Doll C, Schmedding D (2004) External cost of transport. Update study: 169. INFRAS. IWW Universitaet Karlsruhe, Zurich

26. Tabuchi T (1998) Urban Agglomeration and Dispersion: A Synthesis of Alonso and Krugman. Journal of Urban Economics, 44:333-351 